\title{
Pedagogical Problems in Mathematical Training of Future Bachelor Engineers at Technical Universities
}

\author{
Gulaiym Zikirova1, Topchubai Isakov ${ }^{2}$, Erkin Kasymbekov³, \\ Albina Tashtemirova ${ }^{1}$, Zhypargul Abdullaeva ${ }^{*}$ (1) \\ ${ }^{1}$ Department of Mathematics Teaching, Osh Technological University, Osh, Kyrgyzstan \\ ${ }^{2}$ Department of Pedagogical Sciences, Kyrgyz-Uzbek International University named after B. Sydykov, Osh, Kyrgyzstan \\ ${ }^{3}$ Department of Pedagogical Sciences, Osh State Pedagogical University, Osh, Kyrgyzstan \\ ${ }^{4}$ Science and Research Department, Osh State University, Osh, Kyrgyzstan \\ Email: *jypar.science@oshsu.kg
}

How to cite this paper: Zikirova, G., Isakov, T., Kasymbekov, E., Tashtemirova, A., \& Abdullaeva, Z. (2021). Pedagogical Problems in Mathematical Training of Future Bachelor Engineers at Technical Universities. Creative Education, 12, 2277-2282. https://doi.org/10.4236/ce.2021.1210172

Received: September 4, 2021

Accepted: October 11, 2021

Published: October 14, 2021

Copyright $\odot 2021$ by author(s) and Scientific Research Publishing Inc. This work is licensed under the Creative Commons Attribution International License (CC BY 4.0).

http://creativecommons.org/licenses/by/4.0/

\begin{abstract}
In this article analysis of pedagogical research reflecting normative documents of higher education in the field of engineering is described, which shows that they have certain prerequisites and conditions in future engineer professional competence formation. Methods, forms and means of teaching students in technical universities determined. The content of government educational standards in engineering higher education includes humanities, natural sciences, engineering, production and practical components, as well as research, design, organizational, managerial and operational activities for technical university specialties to determine the general types of actions. Main terms such as professiogram with its components and requirements were described, including features, professional work specifics; the specialist model is a set of qualities in a specialist, ensuring successful implementation of problems arising in production and humanitarian activities.
\end{abstract}

\section{Keywords}

Activity, Traditional Training, Competence, Functional, Normative, Methodological, Qualification, Professional Competencies, Professiogram

\section{Introduction}

The pedagogical process in technical universities (Bokareva \& Bokarev, 2013: p. 41 ) is determined by the requirements established by regulations. These documents are the government educational standard for the higher professional edu- 
cation of engineers, professional profile, model of the specialist, the concept of education modernization in the Kyrgyz Republic (Murzaliev, 2020: p. 47).

The first document is based on the government standards qualification model in vocational education, which is currently guided by higher education institutions in our country. It defines "what a specialist should be", what functions he should be trained to perform, what qualities he should have. Such a model is a system-creating factor in the choice of the content of education and the form of its implementation in the learning process. These standards should emphasize the education system dominance, which does not provide the opportunity to assess the quality of education with the indicator "readiness of the graduate for future professional activity".

In the competency-based approach to education (Letina, 2020: p. 2), learning objectives are associated not only with the performance of specific functions but also with the requirements integrated into the results of the educational process.

The second document named professiogram regulates technology of professional requirements formation in human personality, psychological abilities, psycho-physiological capabilities. It describes activity specifics in the specialty, the necessary special training, work and rest, sanitary and hygienic conditions, the typical psycho-physiological condition, the nature and amount of information processed the intellectual and physical burden of work, the means used, human activities, as well as the algorithm and psychological structure of actions.

The professiogram assesses the level of importance of various mental qualities and qualities of the individual for the effective performance of the activity under consideration, to obtain an average assessment of the importance of each mental function necessary to rank individual work operations in the studied activities and functions in the whole educational process (Medina, 2017: p. 1) and allows to determine the requirements for a quality establishment.

Professiogram is a listing in a certain profession, including features, professional work specifics description, and a list of norms and requirements for a person who owns that profession (Tsytsulina et al., 2018: p. 369).

\section{Research Methods}

In this work, various models were determined based on the literature review and analysis; specialist models as successful implementation form of problems arising in production and humanitarian activities during education and competence model of graduate students were considered.

\section{Results and Discussions}

\subsection{Specialist Model}

The specialist model is a set of qualities in a specialist that ensures the successful implementation of problems arising in production and humanitarian activities, as well as a description of self-education and self-development, taking into account the dynamic development of society, institutions and individuals (Ministry of Educa- 
tion and Science of the Kyrgyz Republic, 2003). One of important tasks of higher educational institutions is the training of specialists, who should be able to adapt to changes in their professional life (Belyaeva et al., 2019: p. 1).

Literature analysis has shown that there are different approaches to determining the structure and content of the engineering specialty model. Current social conditions place special demands on the professional activity of the specialist and his/her qualification work as a whole. The content of engineering vocational education is not only based on scientific principles but also includes the value of relationships, the expression of personal creativity and a set of types of engineering professional activities.

This shows the need to develop a model of graduate competence, taking into account the complex content of professional training of students in technical universities. It summarizes the set of competencies formed in the educational process at that time, what should be achieved in the process of personal and professional training of students in higher education.

As noted above, the current state standards of higher education are based on a qualification model of a specialist, which describes what a specialist is capable of, what functions he should be ready to perform and what qualities he should have. Such a model manifests itself as a factor that creates the system by choosing the content of education and as an implementer of its forms in the learning process (Zimnyaya, 2009: p. 12).

It should be noted that the current government standards do not include indicators such as the predominance of knowledge providers and the readiness of graduates for future careers, as well as the ability to assess the quality of education. The model of competence of the graduate also includes categories; the purpose of education depends not only on the performance of specific functions but also on the results of the educational process, the integrated requirements.

N. F. Talyzin notes that the model of activity of the specialist should determine the system of problems that arise after graduation. In its development, it is necessary to take into account the general qualification requirements for the specialist, the description of the field of professionalism, the main types, the content and structure of activities, the personal qualities of the specialist. The specific model created for a specific specialty is characterized by goals, functions, competencies, qualities, knowledge, criteria and rules for achieving goals, information security (Talyzina, 1986).

\subsection{Graduate Competence}

We understand the graduate competence model as the main target result in the process of personal and professional development of the student in the university, which provides skills and training in the professional and socio-cultural sphere. In creating it, we have considered that a clear "basic system will guide self-assessment for opportunities such as the description of integrated personality education through creative qualities." The process of personal formation in the vocational education system is inherent in physiological changes that occur in a per- 
son when mastering a professional activity; professional development of personal includes the accumulation of certain knowledge, mastery of skills and abilities, specific different ways of practical activity and their continuous improvement (Sulima, 2017: p. 74; Chesnokova, 2009: p. 172).

In developing the model of graduate competence, we used the binary classification, which consists of two main groups of competencies: universal (general) and professional, with specific blocks of competencies and they meet the professional and academic requirements for training as shown in Figure 1.

In determining the composition and content of competencies, the opinions and recommendations of research developed by the competence approach, the qualification requirements for graduates, as well as the characteristics of the professional activity of the specialist were considered. Universal competencies are the main basis for the formation of a professional personality in various areas of professional activity, as they ensure the normal life of a person in society.

Competence includes a set of interrelated personalities (knowledge, abilities, skills, methods of activity), formed in relation to a certain range of objects and processes and necessary for high-quality productive activities (Eremina et al., 2015: p. 3).

They allow graduate students adaptation to other related specialties in other areas of activity that are not related to the basic qualifications obtained in higher education institutions in demand in the labor market. In characterizing universal competencies, it is important to take into account the intellectual, cognitive, moral behavior, creativity, communication and other basic personal resources of the individual. Definition of theory or theoretical approach among mathematics education researchers showed large diversity with heterogeneity, a theoretical approach by various researchers and different scholarly traditions (Schindler \& Rott, 2016: p. 3).

Another important document is the Concept of Modernization of Education in the Kyrgyz Republic until 2020, which sets out the main goals of vocational education. The related document "Strategy for Modernization of the Content of General Education" states that "the development of the new economy, the main

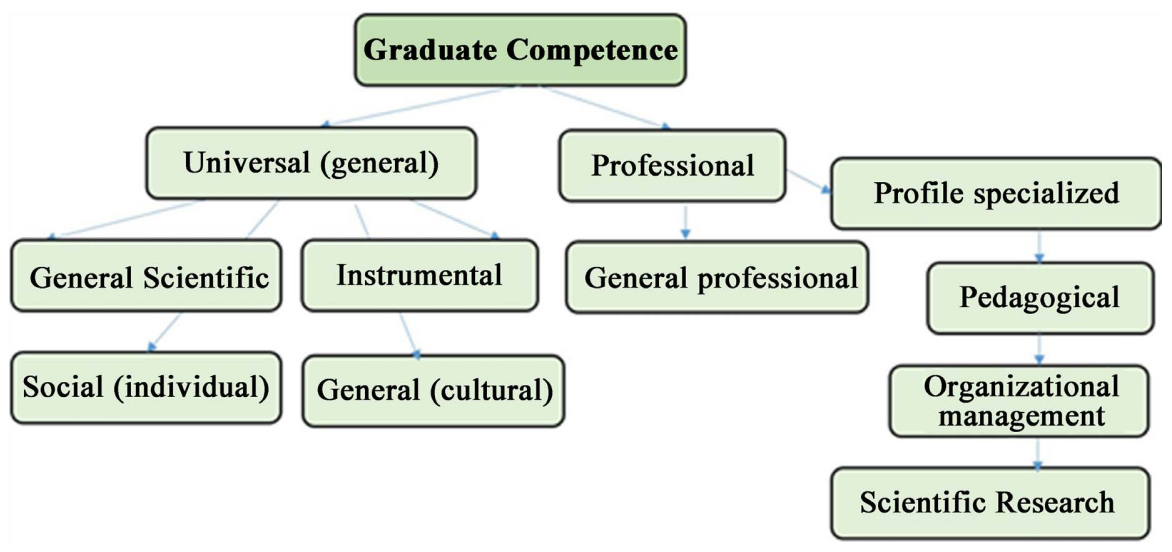

Figure 1. Classifications in graduate competence model. 
resource of which is mobile and highly qualified human capital, requires new achievements in the field of quality education."

In this regard, the main result of the activities of educational institutions should be not only a system of knowledge, skills and abilities but also a set of key competencies in various fields. B. C. Gershunsky believes that the "ladder" of knowledge for a person due to high results can be considered by the following levels of his achievements:

1) Literacy (readiness to further develop and enrich educational potential);

2) Education (literacy that reaches the maximum required for social and personal needs);

3) Professional competence (level of professional education, experience and personal abilities of the person, constant motivated desire for education and selfimprovement, creative and responsible attitude to work); the concept of professional competence is multi-faceted and multi-dimensional, it changes alongside the transformations (Yachina et al., 2009: p. 181; Zhienbayeva et al., 2019: p. 7);

4) Culture (the highest manifestation of human knowledge and professional competence, conscious deep respect for the legacy of the past, the ability to creatively perceive, understand and express the reality of human knowledge and professional environment) (Gershunsky, 1990).

\section{Conclusion}

Summarizing above, the concept of competence determines the depth and nature of future specialist's awareness in specific professional activity and professional space, as well as the ability to effectively implement their professional qualifications and experience in practice (Motornaya, 1997). The model of competence of the graduate also includes categories; the purpose of education depends not only on the performance of specific functions but also on the results of the educational process, the integrated requirements.

Practical implications in this work are based on determined composition and content of competencies, recommendations in research development approach, the qualification requirements for graduates, as well as the professional activity characteristics which are useful in implementation of a problem solution in mathematical training of future bachelors at technical universities.

\section{Conflicts of Interest}

The authors declare no conflicts of interest regarding the publication of this paper.

\section{References}

Belyaeva, I. G., Samorodova, E. A., Voron, O. V., \& Zakirova, E. S. (2019). Analysis of Innovative Methods' Effectiveness in Teaching Foreign Languages for Special Purposes Used for the Formation of Future Specialists' Professional Competencies. Education Sciences, 9, Article No. 171. https://doi.org/10.3390/educsci9030171

Bokareva, G. A., \& Bokarev, M. Yu. (2013). Applied Pedagogy at a Technical University. 
Bulletin of Kazan Technological University, 16, 41-44.

Chesnokova, E. V. (2009). Personal and Professional Development of a Student in a Modern Educational Environment. Bulletin of the Tambov University. Series: Humanities, No. 12, 172-178.

Eremina, A. V., Zoroastrova, I. V., \& Suchkova, E. O. (2015). Identification of Key Competencies of University Graduates. Studia Humanitatis, No. 4, Article No. 5.

Gershunsky, B. S. (1990). Prospects for the Development of a System of Continuous Education (224 Pages). Pedagogika.

Letina, A. (2020). Development of Students' Learning to Learn Competence in Primary Science. Education Sciences, 10, Article No. 325. https://doi.org/10.3390/educsci10110325

Medina, M. S. (2017). Does Competency-Based Education Have a Role in Academic Pharmacy in the United States? Pharmacy, 5, Article No. 13. https://doi.org/10.3390/pharmacy5010013

Ministry of Education and Science of the Kyrgyz Republic (2003). Government Educational Standard of Higher Professional Education 551701, "Electricity".

Motornaya, S. E. (1997). Pedagogical Conditions for the Formation of Readiness Students of a Technical University to Professional Activities (18 Pages). Dissertation, Tomsk.

Murzaliev, M. A. (2020). On the Modernization of the Education Sector in Kyrgyzstan and Interaction with International Institutions. International Journal of Humanities and Natural Sciences, No. 7, 47-51.

Schindler, M., \& Rott, B. (2016). Networking Theories on Giftedness-What We Can Learn from Synthesizing Renzulli's Domain General and Krutetskii's Mathematics-Specific Theory. Education Sciences, 7, Article No. 6.

https://doi.org/10.3390/educsci7010006

Sulima, V. N. (2017). Personal and Professional Development of Students during the Period of Study at a Higher Educational Institution. Bulletin of the Kostroma State University. Series: Pedagogy, Psychology, Sociokinetics, 23, 74-78.

Talyzina, N. F. (1986). Theoretical Foundations for the Development of a Specialist Model(232 Pages). Knowledge.

Tsytsulina, A. A., Shibanova, D.A., \& Shkunova, A. A. (2018). Professiogram as a Tool for Recruiting Employees. Innovative Economy: Prospects for Development and Improvement, 8, 368-374.

Yachina, N. P., Mukhutdinova, T. Z., \& Khazieva, N. N. (2009). Professional Competence as an Indicator of the Quality of Education. Bulletin of Kazan Technological University, No. 2, 180-186.

Zhienbayeva, S., Kalysh, A., Zhubandykova, A., Nabuova, R., Issayeva, A., Abilmazhinova, O., \& Ahmuldinova, A. (2019). The Model of Professional Competence Development in Future Physical Education Teachers at an Entrepreneurial University. Revista Education, 40, Article No. 7.

Zimnyaya, I. A. (2009). Key Competencies Are a New Paradigm of Educational Outcomes. Experiment and Innovation in School, No. 2, 7-14. 